\title{
The Roles of Auxin Biosynthesis YUCCA Gene Family in Plants
}

\author{
Xu Cao ${ }^{1,2}$, Honglei Yang ${ }^{1,2}$, Chunqiong Shang ${ }^{1,2}$, Sang Ma ${ }^{1,2}$, Li Liu ${ }^{1,2}$ and Jialing Cheng ${ }^{1,2, * \mathbb{D}}$ \\ 1 College of Biotechnology, Jiangsu University of Science and Technology, Zhenjiang 212003, China; \\ caoxv618@vip.163.com (X.C.); yanghonglei6@163.com (H.Y.); scqiong9516@163.com (C.S.); \\ 18956336678@163.com (S.M.); touchliu@163.com (L.L.) \\ 2 Key Laboratory of Silkworm and Mulberry Genetic Improvement, Ministry of Agricultural and Rural Areas, \\ Sericultural Research Institute, Chinese Academy of Agricultural Sciences, Zhenjiang 212018, China \\ * Correspondence: chengjialing1@yeah.net; Tel.: +86-511-85616573
}

Received: 2 November 2019; Accepted: 12 December 2019; Published: 16 December 2019

\begin{abstract}
Auxin plays essential roles in plant normal growth and development. The auxin signaling pathway relies on the auxin gradient within tissues and cells, which is facilitated by both local auxin biosynthesis and polar auxin transport (PAT). The TRYPTOPHAN AMINOTRANSFERASE OF ARABIDOPSIS (TAA)/YUCCA (YUC) pathway is the most important and well-characterized pathway that plants deploy to produce auxin. YUCs function as flavin-containing monooxygenases (FMO) catalyzing the rate-limiting irreversible oxidative decarboxylation of indole-3-pyruvate acid (IPyA) to form indole-3-acetic acid (IAA). The spatiotemporal dynamic expression of different YUC gene members finely tunes the local auxin biosynthesis in plants, which contributes to plant development as well as environmental responses. In this review, the recent advances in the identification, evolution, molecular structures, and functions in plant development and stress response regarding the YUC gene family are addressed.
\end{abstract}

Keywords: auxin; local auxin biosynthesis; YUCCA; development; stress response

\section{Introduction}

Auxins represent a category of low molecular weight organic acids containing both an aromatic ring and a carboxylic acid side chain within $0.55 \AA$ distance so that the compounds can be bioactive [1]. Indole-3-acetic acid (IAA), 4-chloroindole-3-acetic acid (4-Cl-IAA), and phenylacetic acid (PAA) are three naturally occurring compounds with direct auxin activity in plants [1,2]. Indole-3-butyric acid (IBA), although presenting similar structure and function in plant growth and development, is defined here as an IAA precursor because it can directly evoke auxin signaling and response only after being converted to IAA [3-5]. In addition to this, a diverse group of synthetic compounds with similar structure and activity of the endogenous auxins (termed synthetic auxin analogues), such as 1-naphthaleneacetic acid (NAA), 2-(2,4-dichlorophenoxy) propionic acid (2,4-DP), 2,4,5-trichlorophenoxyacetic acid (2,4,5-T), 2,4-dichlorophenoxyacetic acid (2,4-D), dicamba, picloram, quinclorac, and so on, is widely used as chemical tools in scientific and agronomic practices [2]. Amongst all the discovered naturally occurring endogenous auxins in plants, IAA has been well and widely characterized so far, and auxin refers to IAA in plants by strict definition [2]. The auxin functions in diverse cellular and developmental responses during plant lifespan, such as adventitious root initiation, apical dominance, vascular tissue formation, tropic responses, and flower and fruit development [6,7], which need the coordination of several complex processes, such as auxin metabolism, auxin transport, and auxin signaling pathway [6,8-10].

In Arabidopsis, IAA can be synthesized by both tryptophan (Trp)-dependent and -independent ways and the Trp-dependent way is much better characterized compared to the other one [10]. The Trp-dependent way includes four pathways utilizing different substrates derived from Trp metabolism, namely, 
indole-3-acetaldoxime (IAOx), indole-3-acetamide (IAM), indole-3-pyruvic acid (IPyA), and tryptamine (TAM) (Figure 1) [11-13]. However, only the IPyA pathway in plants has been firmly completed, which consists of a two-step reaction converting the Trp into IAA [10,12]. In this pathway, IAA is firstly converted into IPyA by a reversible amino transfer reaction with the help of TRYPTOPHAN AMINOTRANSFERASE OF ARABIDOPSIS (TAA) [10]. The level of IPyA is steadily maintained since IPyA can be efficiently converted back to Trp by VAS1 (reversal of SAV1) using methionine (Met) as amino donor [11]. Then, YUCCA (YUC)-type flavin-containing monooxygenases (FMO) catalyze the rate-limiting irreversible reaction: the oxidative decarboxylation of IPyA to form IAA [14,15]. The formed IAA can be either conjugated by Gretchen Hagen 3 (GH3) to form IAA-amino acid conjugates or irreversibly oxidized by Dioxygenase for Auxin Oxidation (DAO) for degradation [16-18].

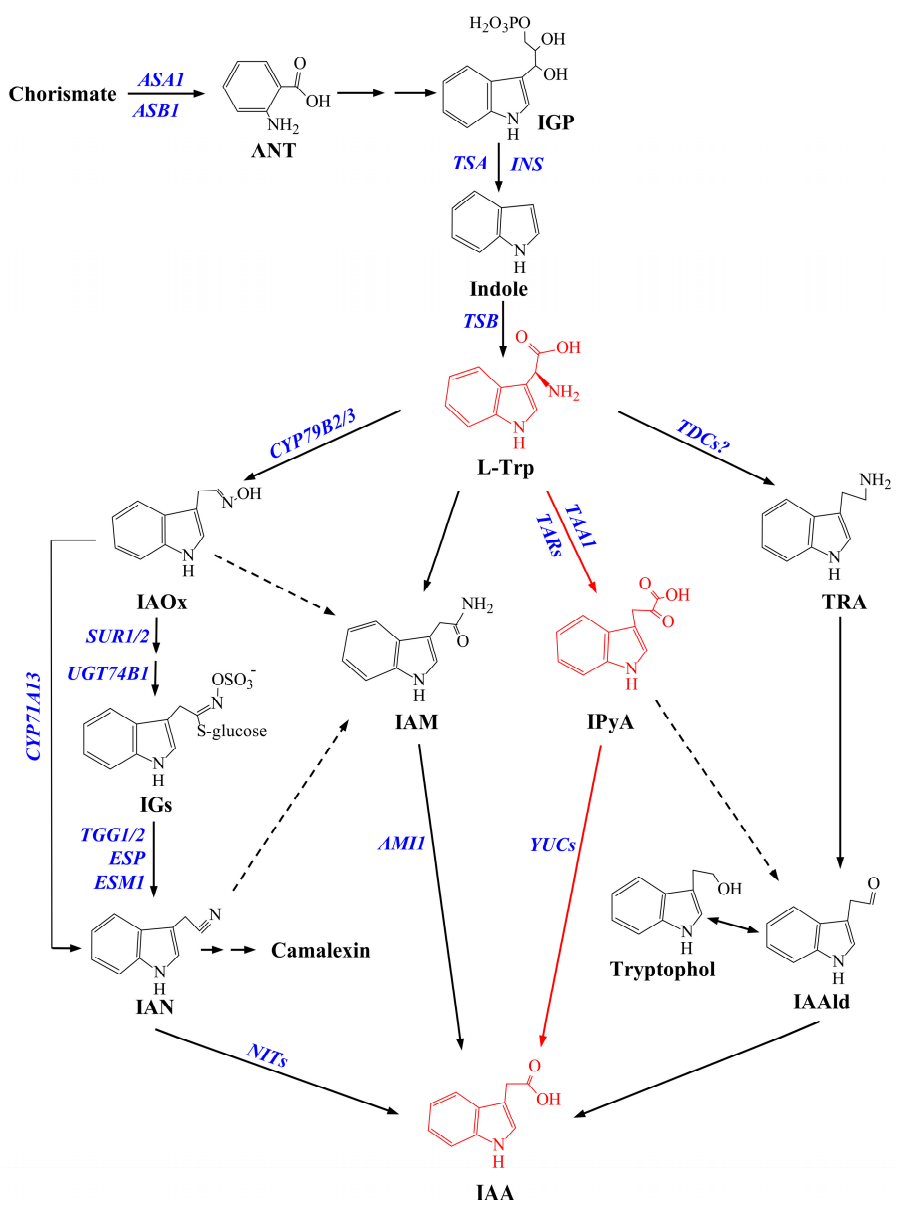

Figure 1. The auxin biosynthesis pathways identified in plants: Solid arrows indicate pathways in which the enzymes, genes, or intermediates are known, and dashed arrows indicate pathways that are not well defined. The TRYPTOPHAN AMINOTRANSFERASE OF ARABIDOPSIS /YUCCA (TAA/YUC) pathway is depicted in red. Gene abbreviations of the enzymes catalyzing the metabolic reactions are given in blue upper-case italics. AMI1: amidase 1; ANT: anthranilate; ASA1: anthranilate synthase $\alpha$ subunit 1 ; ASB1: anthranilate synthase $\beta$ subunit $1 ; C Y P 71 A 13$ : indoleacetaldoxime dehydratase 71A13; CYP79B: cytochrome P450 monooxygenase 79B; ESM: epithiospecifier modifier; ESP: epithiospecifier; IAA: indole-3-acetic acid; IAAld: indole-3-acetaldehyde; IAM: indole-3-acetamide; IAN: indole-3-acetonitrile; IAOx: indole-3-acetaldoxime; IGP: indole-3-glycerol phosphate; IGs: indole glucosinolates; INS: indole synthase; IPyA: indole-3-pyruvic acid; L-Trp: L-tryptophan; NITs: nitrilase; SUR: S-alkyl-thiohydroximate lyase; TAA1: tryptophan aminotransferase of Arabidopsis 1; TARs: tryptophan aminotransferases; TDCs: tryptophan decarboxylases; TGG: myrosinase; TRA: tryptamine; TSA: tryptophan synthase subunit A; TSB: tryptophan synthase subunit B; UGT74B1: UDP-glycosyltransferase 74B1; YUCs: YUCCAs. 
The TAA/YUC pathway stands as the primary endogenous auxin biosynthesis pathway that involves in major biological processes mediated by the activity of auxin, and the conservation of this pathway in the plant kingdom has been functionally checked in many plant species [10,19-24]. There are 5 TAA and 11 YUC gene members identified in the genome of Arabidopsis [15,25]. TAA proteins appear to present broadly at the organ level, whereas YUC enzymes exhibit more distinct organ-specific expressions and stricter subcellular compartmentations $[10,25,26]$. For instance, YUC1, 2, 4, and 6 mainly function in shoots, and YUC3, 5, and 7-9 are expressed during root development [27]. The spatiotemporally similar co-expression of specific combinations of TAA and YUC members are required to ensure correct organ development, as reviewed in detail previously [10,26]. Recently, local auxin biosynthesis is emphasized to play important roles in major developmental processes in plants $[2,10,13,25,28]$. One typical example is that a YUC gene expressed in shoots failed to complement the phenotypes of root-localized YUC mutants [27]. New results showed that the maxima and minima of the auxin within tissues are not determined solely by polar auxin transport (PAT); local auxin biosynthesis also contributes greatly to optimizing plant growth in response to changeable environments [10,27-29]. Here, we review the recent advances on the YUC gene family; their identification, evolution, molecular structure, and functions in plant development and stress response will be addressed.

\section{Identification and Evolution of YUC Gene Family}

YUC genes were firstly identified from an activation-tagged line showing developmental defects caused by auxin overproduction in Arabidopsis [15]. Since the mature yuc mutant had curled downward leaves and semi-erect growth habit, which resembled the commonly known yucca plant (Agave sp.), they were named after the yucca plant and the gene identified was named YUCCA (YUC) [15]. YUC enzymes are encoded by a relatively small gene family compared to genes involved in auxin transport [6] or signaling [8,30]. By genome-wide phylogenetic analysis, the YUC gene family has been identified in over 20 plant species (Table 1), including 11 genes in Arabidopsis thaliana [31], 9 in Cucumis melo [32], 10 in Cucumis sativus [33], 8 in Fragaria vesca [23], 14 in Medicago truncatula [34], 22 in Glycine max [35], 13 in Phyllostachys heterocycla [36], 12 in Populus trichocarpa [37], 14 in Oryza sativa [38], and 14 in Zea mays [39]. Increasing YUC genes were isolated in more plant species [40-42]. Consistent with the importance of the TAA/YUC pathway in flowering land plants, it appears that this pathway is likely to be evolutionarily conserved in basal plants such as mosses and photosynthetic algae [43,44]. Mutational loss of YUC in liverwort Marchantia polymorpha caused absolute failure in tissue patterning [45]. Functional studies have found that overexpression of the SHORT INTERNODE/STYLISH (SHI/STY) genes, a transcription activator which directly binds to the promoter of YUC genes in Arabidopsis [46,47], resulted in an elevated auxin biosynthesis in moss Physcomitrella patens [48]. Nevertheless, it remains unclear whether other unique pathways besides TAA/YUC may exist in early diverging plants [49]. 
Table 1. Summary of YUC proteins that identified in 27 plants.

\begin{tabular}{|c|c|c|c|c|c|c|c|}
\hline Species & $\begin{array}{c}\text { Genome } \\
\text { Size }(\mathrm{Mb})\end{array}$ & Protein No. & Reference & Species & $\begin{array}{c}\text { Genome Size } \\
(\mathrm{Mb})\end{array}$ & Protein No. & Reference \\
\hline Arabidopsis thaliana & 135 & 11 & {$[15,31,50,51]$} & Phyllostachys heterocycla & 2050 & 13 & [36] \\
\hline Arabidopsis lyrata & 207 & 11 & [44] & Physcomitrella patens & 473 & 6 & {$[44,52]$} \\
\hline Amborella trichopoda & 748 & 7 & [44] & Phtheirospermum japonicum & - & 4 & [53] \\
\hline Brassica rapa & 284 & 18 & {$[44]$} & Picea abies & 20,000 & 14 & [44] \\
\hline Carica papaya & 135 & 7 & [44] & Pinus lambertiana & - & 8 & [44] \\
\hline Cucumis satious & 203 & 10 & [54] & Prunus persica & 227 & 7 & {$[44]$} \\
\hline Cucumis melo & 375 & 9 & [32] & Populus trichocarpa & 422.9 & 12 & [37] \\
\hline Fragaria vesca & 240 & 8 & {$[23,37]$} & Solanum tuberosum & 723 & 8 & {$[55,56]$} \\
\hline Glycine max & 978 & 22 & {$[34,35]$} & Theobroma cacao & 346 & 7 & {$[44]$} \\
\hline Nelumbo nucifera & 929 & 11 & [44] & Selaginella moellendorffii & 213 & 3 & [44] \\
\hline Marchantia polymorpha & 226 & 2 & [57] & Solanum lycopersicum & 900 & 6 & [41] \\
\hline Medicago truncatula & 360 & 14 & [34] & Vitis vinifera & 487 & 8 & [44] \\
\hline Musa acuminate & 523 & 21 & {$[44]$} & Zea mays & 2300 & 14 & [39] \\
\hline Oryza sativa & 372 & 14 & [58] & & & & \\
\hline
\end{tabular}


In A. thaliana, the 11 YUC genes have strong functional redundancy because severe defects were only found in higher-order YUC mutants [31,59]. YUC gene family has been expanded after multiple rounds of genome duplications in several genome-sequenced plant species such as poplar [37], rice [25], and maize [60]. For instance, PtYUC1 and PtYUC4 orthologs in P. trichocarpa are paralogs and PtYUC2 and PtYUC6 are paralogs [37] as in the case of Arabidopsis, indicating these paralogs were likely produced by genome segment duplication [61].

Phylogenetic analysis demonstrates that YUCs share common ancestors in diverse taxonomic groups including moss, monocots, dicots, and non-seed vascular plants but that YUC proteins have diverged to ensure correct domain specialization [52,62]. However, the origin of YUC genes and even the entire TAA/YUC pathway in plants has been unclear and controversial. Earlier phylogenetic analysis documented that neither TAA nor YUC protein homologs were recognizable in a group of green algae (chlorophytes and charophytes) from which land plants originated and suggested that the YUC gene family in higher plants were derived from horizontal gene transfer from bacteria into the ancestral land plant $[63,64]$. This idea was soon questioned by other phylogenetic analyses with more comprehensive genome and transcriptome data sets, addressing that the canonical land plant auxin biosynthetic pathway is not a land plant innovation $[25,65,66]$. YUC genes appear to be widespread in plants, including basal charophyceae algae more than 500 million year ago $[65,66]$. For now, functional information for charophyte YUC homologs is still insufficient; the origin of plant auxin biosynthesis will continue to be debated before this important issue is well addressed by further functional and phylogenetical analysis with additional genomic and transcriptomic resources. Nevertheless, it is almost certain that $Y U C$ family has greatly diversified due to extensive specialization in eudicots and monocots in the last 150 million years and has independently expanded afterwards [25,60]. For instance, rice YUC4 and YUC5 and maize spi1, a member of a monocot-specific clade of YUC-like genes, share high similarity, but none of them have clear co-orthologue in eudicots [60]. Expression and functional data suggest the diverged role of YUCs in inflorescence development in monocots [60].

\section{Molecular Structures and Cellular Locations of YUC Proteins}

YUC proteins are the first identified category of FMO in plants; they possess typical structures and similar properties as these of mammalian FMO [67]. Bioinformatic and biochemical studies have demonstrated that plant FMO proteins generally harbor six highly conserved motifs (or amino acid residues) (Figure 2) [68,69]. The flavin adenine dinucleotide (FAD)-binding motif and the nicotinamide adenine dinucleotide phosphate (NADPH)-binding motif are featured with the highly conserved GxGxxG sequence, which is well recognized as part of the classic Rossman fold $(\beta \alpha \beta)[70,71]$. The FAD-biding motif resides near the N-terminus, and the NADPH binding motif locates in the middle region. The GG motif (ExxxxxGG) in close proximity to the FAD-binding motif is assumed to stabilize FAD binding [72], and the ATG-containing motif 1 (DxxxxATG) is probably to connect the FAD and NADPH sites [72]. The FMO-identify sequence motif (FxGxxxHxxxY) just occurring before the NADPH-binding domain contributes to NADPH binding [73,74]. The ATG-containing motif 2 in the $C$-terminus often has a conserved $F$ in front of the $A$ and a conserved $Y$ after the $G$, shortly as FATGY [72]. However, the key structures of YUC genes in plants are not fully understood. Recently, several important and conserved residues of YUC proteins in Arabidopsis were identified by allelic analysis. Mutations of the first and third glycines in the FAD-binding motif or of the third glycine in the NADPH-binding motif completely abolished YUC functions in auxin biosynthesis in A. thaliana [75] and maize [60], suggesting that the FAD- and NADPH-binding motif GxGxxG is central to YUC activity. Furthermore, some residues near or within the FAD/NADPH-binding motifs appear to be highly conserved in A. thaliana YUC proteins [75]. For instance, a proline $(\mathrm{P})$ after the second $\mathrm{G}$ and two amino acid residues leucine (L) and alanine (A) following the third $\mathrm{G}$ are relatively conserved in FAD-binding motif (GxGPxGLA). Two amino acid residues methionine $(\mathrm{M})$ and glutamicacid $(\mathrm{E})$ following the last $\mathrm{G}$ in the NADPH-binding site appear conserved (GxGxxGME) [75]. Because YUC proteins are specifically involved in auxin biosynthesis, it is expected that they need ways to sustain precision 
for certain hydroxylation reactions. These highly conserved positions may contribute to substrate specificity of this class of enzymes [75]. Similarly, some amino acid residues with higher occurrences in the FAD- and NADPH-binding sites were also identified in soybean [35]. Further in vitro biochemical and functional analysis of YUC proteins may clarify other indispensable motifs or residues for YUC functions and to understand how YUC activities are regulated.

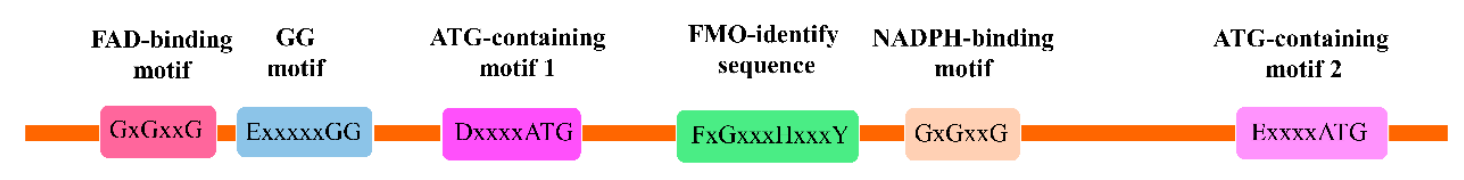

Figure 2. The molecular structure of flavin-containing monooxygenases (FMO) proteins in plants: Several conserved domains closely related to their functions have been identified, including one flavin adenine dinucleotide (FAD)-binding motif, one GG motif, two ATG-containing motifs, one FMO-identify sequence, and one nicotinamide adenine dinucleotide phosphate (NADPH)-binding motif.

The exon/intron organization including exon numbers, locations, and intron lengths of YUC genes varies across different plant species or even within species [41,58]. In Arabidopsis, YUC1 and YUC2 possess four exons intercepted by three introns at the same exact positions but SUPER1 (i.e., YUC5) does not have any introns [50]. Such molecular structure might be related to its lower enzyme activity in auxin biosynthesis compared to other gene members [50]. The coding region of ToFZY3/4/5, the YUC-like genes in cherry tomato, is disrupted by 2 introns, but the first intron is inserted between the same coding positions, which contains the FAD- and NADPH-binding motifs [41].

Since Trp is a precursor for the synthesis of many defense compounds and proteins, compartmentalization of Trp pool or the strict regulation of the downstream steps in IAA biosynthesis is needed to precisely control the IAA turnover [76]. The transmembrane domain structure and subcellular localization of YUC proteins have been proposed to correlate with specific tissue localization and functions $[25,44,77,78]$. For instance, Arabidopsis YUC4 has two major isoforms, with YUC4.2 having a C-terminal hydrophobic transmembrane domain of 24 amino acids due to alternative splicing [79]. This structure leads YUC4.2 to be specifically inserted to the cytosolic face of the endoplasmic reticulum (ER) membrane [80]. Furthermore, the activity of YUC4.2 is restricted to flowers, which supports its specialized role in floral development [31]. ER-targeted subcellular localizations of a subset of YUC supports a model of supplementary layers of auxin function [78]. Phylogenetic analysis indicated an evolutional origin of the ER localization of YUC proteins early in mosses [44]. However, very little is known about the localization of YUC proteins in other subcellular compartments, such as vacuoles and the apoplast [81].

\section{Roles of YUC in Plant Developmental Processes}

Auxins play important roles in a wide range of plant development processes, from the promotion of cell elongation, induction of cell division activity of cambia, and initiation of root and leaf architecture to contributions to flower, embryo, and fruit development $[6,12,25,82]$. Loss of function of multiple YUC genes caused severe developmental defects such as failure in flower formation and embryo development in Arabidopsis [27,59]. Although the mechanisms of auxin biosynthesis seem to be generally conserved, the YUC gene family is capable of rapid functional divergence with the potential to generate novel plant morphologies [34,60]. Additionally, many essential transcriptional factors that transcriptionally regulate YUC-mediated development processes have been identified in the past decades, such as STYLISH 1 (STY1) [47], LEAFY COTYLEDON 2 (LEC2) [83,84], SPOROCYTELESS [85], REVEILLE 1 [86], and PHYTOCHROME INTERACTING FACTOR (PIF) [87-90], which stitch the changes in environmental clues (such as light) as well as developmental processes together with local auxin biosynthesis in plants. 


\subsection{Root Development}

The root system of dicotyledonous plants consists of a primary root and lateral roots, which enable the plants to exploit water and nutrient in the soil [77,91,92]. Root apical meristem has a high rate of IAA biosynthesis due to high expression of genes involved in auxin biosynthesis [93,94]. In combination with PAT [95,96], local auxin biosynthesis converges to establish the critical auxin gradient within the root apex, resulting in changes in auxin homeostasis and root architecture [11]. In Arabidopsis, changes in the expression of the YUC genes have an impact on local auxin biosynthesis [97,98]. Particularly the quintuple mutants yuc3 yuc5 yuc7 yuc8 yuc9 have severely disturbed root growth and gravitropism [27]. Notably, auxin derived from the shoot could not fully rescue the root growth at the root tip with auxin deficiency, highlighting that local auxin biosynthesis and long-distance auxin transport could synergistically regulate auxin homeostasis required for root growth [27]. Antisense expression of YUC1 in rice resulted in a defective root which resembled the root phenotype of auxin-insensitive mutant [99]. The missing YUC6 caused defects in root formation in woodland strawberry (Fragaria vesca L.) [23]. Other evidences suggest that local auxin synthesis might depend upon auxin transport because disruption of the GNOM, which facilitates the cellular trafficking of PIN proteins, led to the decrease of YUC gene expression during lateral root emergence [100]. Multiple YUC genes including YUC3/5/7/8/9 are required for HIGH HOMEODOMAIN-LEUCINE ZIPPER III (HD-ZIP III) expression and metaxylem differentiation in the vascular bundle of Arabidopsis primary root [101]. Crown root initiation and elongation in rice was regulated by a YUC-auxin-WOX11 (WUSCHEL-RELATED HOMEOBOX 11) module [58].

Auxin is the master regulator of adventitious root (AR) formation [102], and other signaling pathways also can mount auxin to shape root architecture, such as nitrate [103]. Numerous studies have demonstrated that early auxin accumulation is a critical signal to initiate cell fate transition of the root founder cells, which is essential for vegetative propagation of plants [104-106]. This auxin peak was the combined outcome of PAT and increased local synthesis in response to multiple exogenous stimuli such as wounding and depletion of water and nutrient $[107,108]$. It is demonstrated that YUC gene family orchestrated endogenous auxin biosynthesis required for AR induction, among which YUC1 and 4 appeared to play the most important role [28,109]. Using transcriptome and genetic approaches, Pan et al. also found that expression of $Y U C 1 / 4$ was critically responsive to the extent of leaf maturation, which in turn largely determined the regeneration capacity of adventitious roots on leaf explant [110]. Several environmental regulators including light [111], sugar availability [76], and circadian rhythms [110] are also involved in the regulation of YUC activity in de novo root development. Furthermore, YUC also participated in regulating plant primary root growth and hypocotyl growth in response to heat stress [87,89] and aluminum (Al) [90], which will be discussed in detail in the later sections.

YUC genes also play a role in the interactions of plant-microbes or plant-plant by regulating auxin levels. Root nodules are a unique type of lateral organ on the roots of most legumes that house nitrogen-fixing bacteria [112]. Although it seems that auxin signaling is crucial for nodulation [113], it was found that rhizobia infection and nodule organogenesis were closely associated with GmYUC2a, an ortholog of Arabidopsis YUC2, to regulate local auxin biosynthesis in legumes [34]. In line with this, GH3s were also found to play a role in regulating proper nodule maturation in soybean [112]. These results highlight the importance of auxin metabolism, besides auxin transport, in legume nodulation. Moreover, in the root parasitic plant Phtheirospermum japonicum, the upregulation of YUC3 was an early response to parasitic plants in the host epidermis cells [53]. The spatiotemporal expression of YUC3 at the epidermal cells near the contact site was required for priming haustorium formation, whereas YUC3 knockdown transgenics formed less haustoria than wildtype plants [53].

\subsection{Leaf Morphogenesis}

It is well recognized that removal of multiple YUC genes resulted in plants with auxin-deficient phenotypes of narrow leaves [15,59], whereas auxin overproduction resulted in curled leaves [114]. Leaf adaxial-abaxial polarity formed at the primordium stage was vital for succeeding leaf expansion [115,116]. 
This process was involved in local auxin accumulation in leaf margin cells [117,118], which was mediated by several YUC genes [115]. Similarly, transgenic Arabidopsis plants harboring soybean (Glycine max) Gm YUC5 displayed downward curling of the leaf blade margin [32,35], suggesting the functional conservation of YUC genes in both plant species. Mutants of $Y U C 1 / 2 / 4 / 6$ caused a reduced number of leaf vein and vascular strands, and this phenotypic strength was highly dependent on the gene dosage of these four YUC genes, suggesting that locally produced auxin is important for vascular strand formation [31]. However, yuc1 yuc4 double mutants showed no obvious defects in leaf formation with regard to the number and position of the leaves. yuc1 yuc4 pin1 triple mutants, however, failed to form true leaves, demonstrating that YUC and PIN1 genes synergistically control leaf development [59]. Increased expression of YUC8/9 is important for leaf heteroblastic development in rainforest tree Gevuina avellane to adapt to different light environment [119]. Moreover, YUC genes have been shown to regulate leaf angle in both monocots and dicots. Arabidopsis YUC6 homologs in potato and oilseed rape (Brassica napus L.) were identified to affect leaf angle modulation [55,120]. Additionally, it is found that a dominant activation mutant yuc6-1D and 35S:YUC6 transgenic plants displayed a delayed senescence phenotype, which was closely related to the elevated auxin levels in leaves [121]. Overproduction of auxins repressed the transcription of several known senescence-associated transcription factors including SENESCENCE ASSOCIATED GENE 12 (SAG12), $N A C 1$, and NAC6 [121]. Overexpression of YUC8 and YUC9 led to aberrant secondary growth of the stem and narrow leaves in Arabidopsis [122]. Genetic and phenotypic analysis showed that YUC2 and YUC6, two key genes essential for leaf development, may be indirectly repressed by SPOROCYTELESS/NOZZLE (SPL/NZZ) transcription factor to regulate auxin homeostasis in lateral organ morphogenesis, including leaf [85]. Additionally, AP2 PLETHORA transcription factors were also found to regulate lateral organ out-growth via the regulation of localized auxin synthesis controlled by YUCs [123].

\subsection{Reproductive Development}

One of the earliest assigned functions of YUC genes were their expression in reproductive organs in Arabidopsis [31,59]. In floral organs, initiation of flower primordia correlated well with the transcriptional levels of YUC1 and YUC4 [31]. It was also found that SUPER1, which encoded YUC5, was largely parallel but partially interacted to the ERECTA receptor signaling pathway during elaboration of Arabidopsis inflorescence architecture [50]. Several lines of evidence have confirmed the synergic interaction between auxin biosynthesis and auxin transport, with both being required for plant development $[59,60]$. It was demonstrated that spi1-mediated auxin biosynthesis was required for upregulation of ZmPIN1a expression during axillary meristem initiation in maize inflorescence development [60]. In flowering plants, the patterning of female gametophytes depended upon an asymmetric distribution of auxin which is primarily correlated with local accumulation of auxin mediated by YUC genes rather than auxin transport [124].

YUC1/4/10/11 is required for the establishment of the basal part of the embryo and for the initiation of embryonic organs [59]. Specifically, YUC1, 3, 4, 8, and 9 were found to be involved in the control of localized auxin biosynthesis in early initiation of embryos during plant embryogenesis [125]. This process was further transcriptionally mediated by a decreased ethylene biosynthesis and signaling to induce YUC expression and to establish the local auxin distribution for somatic embryo initiation [126]. Other studies showed that YUC genes were regulated by LEC2 transcription factor in somatic embryogenic induction and that the interaction of LEC 2 with the promotor of YUC4 was evidenced by chromatin immunoprecipitation $[83,84]$.

Auxin plays a critical role in fruit development, beginning with flower formation and patterning of the gynoecium, through fruit set, fruit growth, and ripening $[127,128]$. Exogenous application of auxin to ovaries can bypass the requirement of pollination producing seedless fruit. A number of studies showed that genes expressions of several YUC were high in seed tissue such as maize [60], rice [129], melon [32], and strawberry [42], suggesting that auxin biosynthesis via the TAA/YUC pathway is likely dominant in fruit. Nevertheless, alternative pathways may also be active depending on the species and developmental stage. For example, members of the tomato YUC family, particularly ToFZY6, showed preferential expression in 
seed [41] but exhibited low expression in apple fruit [130]. Furthermore, by combining RNA-seq technique and laser capture microdissection, transcription factor PLETHORA, which has been implicated in regulating the expression of YUC1 and YUC4 [123], was co-expressed with auxin reporter DR5 activity in funiculus, where auxin accumulated in a tissue-specific manner in tomato fruit [131].

\section{Roles of YUCCA in Response to Abiotic Stress}

Plant can exploit various steps within the auxin biosynthetic pathway to generate the extra auxin required to reprogram the expression of the genes involved in stress responses [132]. The YUC gene family also mediates the local auxin biosynthesis, which is essential for plants adapting to various adverse environmental conditions, such as drought, metal stress, heat stress, as well as shade [26].

\subsection{Drought Stress}

Drought is one of the most frequent environmental stresses, which causes severe yield losses for crops and tree mortality in forests in the context of global climate change in recent decades [54,133-135]. Amongst all the known phytohormones, abscisic acid (ABA) has been considered as the most relevant hormone to regulate plant drought response due to its predominant roles in controlling stomatal opening [136,137]. However, recent studies have provided some evidences that auxin biosynthesis mediated by YUC is essential for plants adapting to drought stress [138,139]. For instance, lower reduction of plant weight was found in auxin-overproduced Arabidopsis seedlings overexpressing YUC8/9 relative to the wildtype when exposed to vaporization at room temperatures, which suggested an increased capacity to sustain tissue water in Arabidopsis [122]. Arabidopsis YUC7 gene functioned in an ABA-dependent manner in response to drought stress; the stomatal aperture and osmoregulators remained unchanged in the gain-of-function yuc $7 D-1$ mutant with drought treatment [140]. The yuc7D-1 mutant had more auxin levels with elevated resistance to drought stress, which was consistent with the upregulated expression level of several drought responsive genes and the more lateral root under drought condition [140]. Furthermore, overexpression of YUC6 in Arabidopsis confirmed the roles of YUC gene in drought tolerance [138]. The yuc1 yuc2 yuc6 triple mutants significantly reduced endogenous IAA level with impaired drought tolerance compared to wildtype plants under drought conditions [139]. In addition to Arabidopsis, heterologous overexpression of AtYUC6 in potato (Solanum tuberosum cv. Jowon) led to highly accumulated auxin and the transgenics displayed higher drought tolerance compared to wildtype plants, which might be attributed to the higher capacities to maintain low levels of reactive oxygen species (ROS) under drought stress in transgenic plants $[55,56]$. In rice, the seedlings with the inactivation of a YUC gene called CONSTITUTIVELY WILTED 1 (COW1) displayed typical wilting phenotypes, such as rolled leaves and reduced root to shoot ratios; these phenotypes are closely associated with the deficit in water uptake, suggesting the important roles that OsCOW1 plays in water homeostasis [38].

These results coincidently imply the important roles of the YUC-mediated auxin synthesis in regulating plant drought stress, and the possible mechanisms have been attributed to the higher level of auxin produced by YUC (1) to improve the root architecture, which is one of the determining factors for plant drought tolerance; (2) to rapidly induce the drought- and/or ABA-responsive genes; (3) to maintain the ROS homeostasis; and (4) to improve the nutrition status of the plants [26,139]. However, further experimental evidence has overturned this point of view [138]. It was demonstrated that the enhanced drought tolerance in the YUC6 overexpression Arabidopsis lines was not due to the increased IAA production but to the novel thiol-reductase (TR) activity of Arabidopsis YUC6 [138]. One important line of evidence was that co-expression of yuc6-1D and 35S:iaaL, a CaMV35S promotor driving IAA-lysine synthase from bacteria to reduce active IAA level, did not affect drought tolerance compared to the yuc6-1D line. On the other hand, overexpression of cytochrome $\mathrm{P} 450$ protein $79 \mathrm{~B} 2$, which also produced high auxin levels through the IAOx pathway, were as sensitive as the wildtype plants under drought stress. Sequence analysis found that YUC6 proteins and flavin-dependent reductases shared slight but noticeable sequence similarities, within which resided the overlapping catalytic domains of TR and FMO [138]. 
Consequently, YUC6 overexpression strengthened both TR activity and IAA level, but it was the former one which endowed the seedlings of enhanced drought tolerance. Physio-biochemical analyses and gene expression assays indicate that the upregulation of peroxidase activity and other redox homeostasis genes improved ROS scavenging capacity and, therefore, drought tolerance [138]. Moreover, YUC6 itself could display holdase chaperone activity, which could also possibly provide protection against drought-induced oxidative stress [138]. This study offers new insights into elucidating the molecular basis of YUC6 in conferring drought stress, which might be applicable to other members of YUC family as the essential Cys-85 in all Arabidopsis YUC is highly conserved $[138,140]$.

\subsection{Al Stress}

During Al stress, the high expression of $Y U C 3 / 5 / 7 / 8 / 9$ in the root-apex transition zone was consistent with the accumulation of auxin, which impaired the root growth in Arabidopsis [90]. This inhibition of root growth was downstream of ethylene signaling, since the ethylene-insensitive 3 (EIN3) and PIF4 directly regulated the expression levels of YUC9 and YUC5/8/9, respectively [90]. Furthermore, PIF4 positively regulated inhibition of root growth induced by Al stress by promoting the expression levels of several YUCS that changed the local auxin biosynthesis and signaling [90]. This model provides the molecular mechanisms of an integration of ethylene and auxin signaling pathways in regulating root growth upon metal stress.

\subsection{Heat Stress}

In addition to $\mathrm{Al}$ stress, YUC-mediated local auxin biosynthesis also contributes to the adaptive strategies of plants to heat stress. For instance, the increased level of IAA was associated with the highly accumulated mRNA levels of two YUCs (e.g., YUC8 and 9) in Cucumis sativus L. after $3 \mathrm{~h}$ of high temperature $\left(38^{\circ} \mathrm{C}\right)$ exposure [33]. RNA-seq data showed that the expression level of YUC9 was highly upregulated compared to other members of YUC gene family in the leaves of Arabidopsis that suffered from heat stress [26]. Furthermore, the increased IAA levels upon high temperature was proven to be under the control of the PIF4-YUC8 module, where PIF4 transcriptionally activated YUC8 expression to shape the plant architecture under high temperature [87]. However, the high temperature-induced transcriptional activation of YUC8 by the activities of PIF4 can be attenuated by both cryptochrome 1 (CRY1) and the RNA-binding protein FCA, a critical component of the autonomous flowering pathway in Arabidopsis [141,142]. In barley and Arabidopsis, the endogenous auxin levels were decreased with lower mRNA levels of YUC in the developing anthers of both plants upon high temperature, which led to plant male sterility, and this abortion of pollen development could be rescued by exogenous application of auxin [143]. These results suggest that the YUC-mediated auxin signaling in response to high temperature is dependent on plant tissues [144].

\subsection{Shade Avoidance}

Light is the one of the most important resources that plants need for normal growth and development, since light not only provides the energy essential for photosynthesis but also regulates plant morphogenesis $[145,146]$. The adaptive strategies called shade avoidance syndrome (SAS) and neighbor detection endow plants the capacities of growing fast and of reaching light quickly when they sense competitors for light, thereby avoiding suffering from shade conditions $[10,147]$. The SAS is triggered by high plant densities when the plants perceive light with decreased red to far-red ratio (R:FR) [148]. The expression levels of $Y U C$ 2, 5, 8, and 9 were rapidly induced upon low R:FR and/or shade signals [148-151]. However, the single yuc mutant (such as yuc1 and 4) and even yuc3 yuc5 yuc7 yuc8 yuc9 quintuple mutants just had minimal to moderate phenotypes of shade avoidance [148,152], except that the yuc2 yuc5 yuc8 yuc9 quadruple mutant held strong phenotypes upon several shade conditions [153]. A comparative transcriptome analysis between wildtypes and the pifq mutant identified a set of PIF-dependent auxin-related genes that highly accumulated under stimulated shade; ca. $73 \%$ of these genes were the known downstream of several PIFs, such as PIF3, 
4 and/or 5 [154], suggesting the hub role of PIFs in auxin-mediated response to shade condition. Furthermore, the expression levels of $Y U C 3,5,6,8$, and 9 upon shade were dependent on the activities of several PIFs $[152,155,156]$ and the PIF-YUC module controlled the leaf hyponasty in response to low R/FR ratio [147]. Impairing the activities of PIFs reduced the expression levels of YUCs in response to shade [154]. The E3 ligase CONSTITUTIVE PHOTOMORPHOGENESIS 1 (COP1) was required for the shade-avoidance responses mediated by the PIF-dependent auxin biosynthesis, COP1-stabilized PIFs by promoting the degradation of LONG HYPOCOTYL IN FAR-RED (HFR1) to potentiate the mRNA levels of YUCs $[154,157]$. Thus, the accumulation of auxin upon shade was linked to the promoted activities of PIFs, which further positively activated the expression levels of certain YUC genes [158].

\section{Conclusions and Outlooks}

Auxin, although a small molecule, affects every aspect in plant growth and development. Since the first functional identification of YUC gene, remarkable progresses have been made in understanding the roles of YUC gene family and the importance of IPyA pathway to ensure auxin homeostasis required for normal plant development as well as for responding to environmental stresses. However, there are still many knowledge gaps to be filled. For instance, only limited information is available for the molecular modifications of YUC genes or proteins to regulate active auxin levels. It was found that active auxin itself could regulate $Y U C$ gene expressions via a negative feedback manner in Arabidopsis [159,160]. Under excess auxin conditions, the four essential YUCS (YUC1, 2, 4, and 6) were transcriptionally downregulated and upregulated under auxin-deficient conditions [159]. However, the underlying regulation of YUC enzyme activity in response to auxin fluctuations has not been reported [159]. Moreover, several important issues, such as how the YUC is regulated by auxin levels during plant development and whether these regulatory mechanisms are at work in other taxonomic groups, remain to be addressed in the future. Chromatin modification was suggested to play important roles in regulating YUCs expression via $\mathrm{H} 3$ methylation, namely H3K27me3, to control cellular auxin concentration [161]. Do et al. [162] have illustrated a precise and systemic picture of the emerging functions of chromatin modifications in YUCS in response to environmental alterations. However, translational and posttranslational regulations of YUC proteins remain largely unclear compared with other gene families in auxin biology, which needs further exploration. Moreover, several effective chemical inhibitors that specifically target YUC enzymes have been developed [163,164]. In the future, traditional genetic and biochemical approaches, combined with these inhibitors that temporally reduce the auxin accumulation, will provide powerful tools to clarify the roles of YUC and the function of the TAA/YUC pathway in diverse physiological or developmental phenomena across the plant kingdom.

Author Contributions: X.C. and J.C. conceptualized the paper; X.C. and H.Y. wrote the paper; C.S. and S.M. prepared the figures; and L.L. and J.C. revised the paper and provided supervision. All the authors read and approved the final manuscript.

Funding: This research was financially supported by the National Natural Science Foundation of China (Grant No. 31670306 and 31700527), Research Fund of Jiangsu University of Science and Technology (Grant No. 1732931608), and China Agriculture Research System (Grant No. CARS-18).

Conflicts of Interest: The authors declare no conflict of interest. The funders had no role in the design of the study; in the collection, analyses, or interpretation of data; in the writing of the manuscript; or in the decision to publish the results.

\section{References}

1. Sauer, M.; Robert, S.; Kleine-Vehn, J. Auxin: Simply complicated. J. Exp. Bot. 2013, 64, 2565-2577. [CrossRef] [PubMed]

2. Ma, Q.; Grones, P.; Robert, S. Auxin signaling: A big question to be addressed by small molecules. J. Exp. Bot. 2017, 69, 313-328. [CrossRef] [PubMed]

3. Shimizu-Mitao, Y.; Kakimoto, T. Auxin sensitivities of all Arabidopsis Aux/IAAs for degradation in the presence of every TIR1/AFB. Plant Cell Physiol. 2014, 55, 1450-1459. [CrossRef] [PubMed] 
4. Uzunova, V.V.; Quareshy, M.; del Genio, C.I.; Napier, R.M. Tomographic docking suggests the mechanism of auxin receptor TIR1 selectivity. Open Biol. 2016, 6, 160139. [CrossRef]

5. Damodaran, S.; Strader, L.C. Indole 3-butyric acid metabolism and transport in Arabidopsis thaliana. Front. Plant Sci. 2019, 10, 851. [CrossRef]

6. Zhou, J.J.; Luo, J. The PIN-FORMED auxin efflux carriers in plants. Int. J. Mol. Sci. 2018, 19, 2759. [CrossRef]

7. Guilfoyle, T.J.; Hagen, G. Auxin response factors. Curr. Opin. Plant Biol. 2007, 10, 453-460. [CrossRef]

8. Luo, J.; Zhou, J.J.; Zhang, J.Z. Aux/IAA gene family in plants: Molecular structure, regulation, and function. Int. J. Mol. Sci. 2018, 19, 259. [CrossRef]

9. Li, S.B.; Xie, Z.Z.; Hu, C.G.; Zhang, J.Z. A review of auxin response factors (ARFs) in plants. Front. Plant Sci. 2016, 7, 47. [CrossRef]

10. Zhao, Y. Essential roles of local auxin biosynthesis in plant development and in adaptation to environmental changes. Annu. Rev. Plant Biol. 2018, 69, 417-435. [CrossRef]

11. Olatunji, D.; Geelen, D.; Verstraeten, I. Control of endogenous auxin levels in plant root development. Int. J. Mol. Sci. 2017, 18, 2587. [CrossRef] [PubMed]

12. Casanova-Sáez, R.; Voß, U. Auxin metabolism controls developmental decisions in land plants. Trends Plant Sci. 2019, 24, 741-754.

13. Zhao, Y. Auxin biosynthesis and its role in plant development. Annu. Rev. Plant Biol. 2010, 61, 49-64. [CrossRef] [PubMed]

14. Zheng, Z.; Guo, Y.; Novák, O.; Dai, X.; Zhao, Y.; Ljung, K.; Noel, J.P.; Chory, J. Coordination of auxin and ethylene biosynthesis by the aminotransferase VAS1. Nat. Chem. Biol. 2013, 9, 244. [CrossRef]

15. Zhao, Y.; Christensen, S.K.; Fankhauser, C.; Cashman, J.R.; Cohen, J.D.; Weigel, D.; Chory, J. A role for flavin monooxygenase-like enzymes in auxin biosynthesis. Science 2001, 291, 306-309. [CrossRef]

16. Zheng, Z.; Guo, Y.; Novák, O.; Chen, W.; Ljung, K.; Noel, J.P.; Chory, J. Local auxin metabolism regulates environment-induced hypocotyl elongation. Nat. Plants 2016, 2, 16025. [CrossRef]

17. Zhang, J.; Lin, J.E.; Harris, C.; Pereira, F.C.M.; Wu, F.; Blakeslee, J.J.; Peer, W.A. Dao1 catalyzes temporal and tissue-specific oxidative inactivation of auxin in Arabidopsis thaliana. Proc. Natl. Acad. Sci. USA 2016, 113, 11010-11015. [CrossRef]

18. Zhang, J.; Peer, W.A. Auxin homeostasis: The DAO of catabolism. J. Exp. Bot. 2017, 68, 3145-3154. [CrossRef]

19. Stepanova, A.N.; Yun, J.; Robles, L.M.; Novak, O.; He, W.; Guo, H.; Ljung, K.; Alonso, J.M. The Arabidopsis YUCCA1 flavin monooxygenase functions in the indole-3-pyruvic acid branch of auxin biosynthesis. Plant Cell 2011, 23, 3961-3973. [CrossRef]

20. Yoshikawa, T.; Ito, M.; Sumikura, T.; Nakayama, A.; Nishimura, T.; Kitano, H.; Yamaguchi, I.; Koshiba, T.; Hibara, K.I.; Nagato, Y.; et al. The rice FISH BONE gene encodes a tryptophan aminotransferase, which affects pleiotropic auxin-related processes. Plant J. 2014, 78, 927-936. [CrossRef]

21. Phillips, K.A.; Skirpan, A.L.; Liu, X.; Christensen, A.; Slewinski, T.L.; Hudson, C.; Barazesh, S.; Cohen, J.D.; Malcomber, S.; McSteen, P. vanishing tassel2 encodes a grass-specific tryptophan aminotransferase required for vegetative and reproductive development in maize. Plant Cell 2011, 23, 550-566. [CrossRef] [PubMed]

22. Pacheco-Villalobos, D.; Sankar, M.; Ljung, K.; Hardtke, C.S. Disturbed local auxin homeostasis enhances cellular anisotropy and reveals alternative wiring of auxin-ethylene crosstalk in Brachypodium distachyon seminal roots. PLoS Genet. 2013, 9, e1003564. [CrossRef] [PubMed]

23. Liu, H.; Xie, W.F.; Zhang, L.; Valpuesta, V.; Ye, Z.W.; Gao, Q.H.; Duan, K. Auxin biosynthesis by the YUCCA6 flavin monooxygenase gene in woodland strawberry. J. Integr. Plant Biol. 2014, 56, 350-363. [CrossRef] [PubMed]

24. Liu, H.; Ying, Y.Y.; Zhang, L.; Gao, Q.H.; Li, J.; Zhang, Z.; Fang, J.G.; Duan, K. Isolation and characterization of two YUCCA flavin monooxygenase genes from cultivated strawberry (Fragaria $\times$ ananassa Duch.). Plant Cell Rep. 2012, 31, 1425-1435. [CrossRef] [PubMed]

25. Matthes, M.S.; Best, N.B.; Robil, J.M.; Malcomber, S.; Gallavotti, A.; McSteen, P. Auxin evodevo: Conservation and diversification of genes regulating auxin biosynthesis, transport, and signaling. Mol. Plant 2019, 12, 298-320. [CrossRef]

26. Blakeslee, J.J.; Spatola Rossi, T.; Kriechbaumer, V. Auxin biosynthesis: Spatial regulation and adaptation to stress. J. Exp. Bot. 2019, 70, 5041-5049. [CrossRef] 
27. Chen, Q.; Dai, X.; De-Paoli, H.; Cheng, Y.; Takebayashi, Y.; Kasahara, H.; Kamiya, Y.; Zhao, Y. Auxin overproduction in shoots cannot rescue auxin deficiencies in Arabidopsis roots. Plant Cell Physiol. 2014, 55, 1072-1079. [CrossRef]

28. Chen, L.; Tong, J.; Xiao, L.; Ruan, Y.; Liu, J.; Zeng, M.; Huang, H.; Wang, J.-W.; Xu, L. YUCCA-mediated auxin biogenesis is required for cell fate transition occurring during de novo root organogenesis in Arabidopsis. J. Exp. Bot. 2016, 67, 4273-4284. [CrossRef]

29. Stepanova, A.N.; Robertson-Hoyt, J.; Yun, J.; Benavente, L.M.; Xie, D.-Y.; Doležal, K.; Schlereth, A.; Jürgens, G.; Alonso, J.M. TAA1-mediated auxin biosynthesis is essential for hormone crosstalk and plant development. Cell 2008, 133, 177-191. [CrossRef]

30. Wu, W.; Liu, Y.; Wang, Y.; Li, H.; Liu, J.; Tan, J.; He, J.; Bai, J.; Ma, H. Evolution analysis of the Aux/IAA gene family in plants shows dual origins and variable nuclear localization signals. Int. J. Mol. Sci. 2017, 18, 2107. [CrossRef]

31. Cheng, Y.; Dai, X.; Zhao, Y. Auxin biosynthesis by the YUCCA flavin monooxygenases controls the formation of floral organs and vascular tissues in Arabidopsis. Genes Dev. 2006, 20, 1790-1799. [CrossRef] [PubMed]

32. Zheng, L.; Zhang, L.; Duan, K.; Zhu, Z.P.; Ye, Z.W.; Gao, Q.H. YUCCA type auxin biosynthesis genes encoding flavin monooxygenases in melon: Genome-wide identification and developmental expression analysis. S. Afr. J. Bot. 2016, 102, 142-152. [CrossRef]

33. Yan, S.; Che, G.; Ding, L.; Chen, Z.; Liu, X.; Wang, H.; Zhao, W.; Ning, K.; Zhao, J.; Tesfamichael, K.; et al. Different cucumber CsYUC genes regulate response to abiotic stresses and flower development. Sci. Rep. 2016, 6, 20760. [CrossRef] [PubMed]

34. Wang, Y.; Yang, W.; Zuo, Y.; Zhu, L.; Hastwell, A.H.; Chen, L.; Tian, Y.; Su, C.; Ferguson, B.J.; Li, X. Gm YUC2a mediates auxin biosynthesis during root development and nodulation in soybean. J. Exp. Bot. 2019, 70, 3165-3176. [CrossRef] [PubMed]

35. Wang, Y.; Liu, H.; Wang, S.; Li, H. Genome-wide identification and expression analysis of the YUCCA gene family in soybean (Glycine max L.). Plant Growth Regul. 2017, 81, 265-275. [CrossRef]

36. Wang, W.; Gu, L.; Ye, S.; Zhang, H.; Cai, C.; Xiang, M.; Gao, Y.; Wang, Q.; Lin, C.; Zhu, Q. Genome-wide analysis and transcriptomic profiling of the auxin biosynthesis, transport and signaling family genes in moso bamboo (Phyllostachys heterocycla). BMC Genom. 2017, 18, 870. [CrossRef]

37. Ye, X.; Kang, B.G.; Osburn, L.D.; Li, Y.; Zong-Ming, C. Identification of the flavin-dependent monooxygenaseencoding YUCCA gene family in Populus trichocarpa and their expression in vegetative tissues and in response to hormone and environmental stresses. Plant Cell Tiss. Org. 2009, 97, 271-283. [CrossRef]

38. Woo, Y.M.; Park, H.J.; Su'udi, M.; Yang, J.I.; Park, J.J.; Back, K.; Park, Y.M.; An, G. Constitutively wilted 1, a member of the rice YUCCA gene family, is required for maintaining water homeostasis and an appropriate root to shoot ratio. Plant Mol. Biol. 2007, 65, 125-136. [CrossRef]

39. Li, W.; Zhao, X.; Zhang, X. Genome-wide analysis and expression patterns of the YUCCA genes in maize. J. Genet. Genom. 2015, 42, 707-710. [CrossRef]

40. Tobeña-Santamaria, R.; Bliek, M.; Ljung, K.; Sandberg, G.; Mol, J.N.M.; Souer, E.; Koes, R. Floozy of petunia is a flavin mono-oxygenase-like protein required for the specification of leaf and flower architecture. Genes Dev. 2002, 16, 753-763. [CrossRef]

41. Expósito-Rodríguez, M.; Borges, A.A.; Borges-Pérez, A.; Pérez, J.A. Gene structure and spatiotemporal expression profile of tomato genes encoding YUCCA-like flavin monooxygenases: The ToFZY gene family. Plant Physol. Biochem. 2011, 49, 782-791. [CrossRef] [PubMed]

42. Feng, J.; Dai, C.; Luo, H.; Han, Y.; Liu, Z.; Kang, C. Reporter gene expression reveals precise auxin synthesis sites during fruit and root development in wild strawberry. J. Exp. Bot. 2019, 70, 563-574. [CrossRef] [PubMed]

43. Zhao, Y. The role of local biosynthesis of auxin and cytokinin in plant development. Curr. Opin. Plant Biol. 2008, 11, 16-22. [CrossRef] [PubMed]

44. Poulet, A.; Kriechbaumer, V. Bioinformatics analysis of phylogeny and transcription of TAA/YUC auxin biosynthetic genes. Int. J. Mol. Sci. 2017, 18, 1791. [CrossRef]

45. Eklund, D.M.; Ishizaki, K.; Flores-Sandoval, E.; Kikuchi, S.; Takebayashi, Y.; Tsukamoto, S.; Hirakawa, Y.; Nonomura, M.; Kato, H.; Kouno, M.; et al. Auxin produced by the indole-3-pyruvic acid pathway regulates development and gemmae dormancy in the liverwort Marchantia polymorpha. Plant Cell 2015, 27, 1650-1669. [CrossRef] 
46. Sohlberg, J.J.; Myrenas, M.; Kuusk, S.; Lagercrantz, U.; Kowalczyk, M.; Sandberg, G.; Sundberg, E. STY1 regulates auxin homeostasis and affects apical-basal patterning of the Arabidopsis gynoecium. Plant J. 2006, 47, 112-123. [CrossRef]

47. Eklund, D.M.; Staldal, V.; Valsecchi, I.; Cierlik, I.; Eriksson, C.; Hiratsu, K.; Ohme-Takagi, M.; Sundstrom, J.F.; Thelander, M.; Ezcurra, I.; et al. The Arabidopsis thaliana STYLISH1 protein acts as a transcriptional activator regulating auxin biosynthesis. Plant Cell 2010, 22, 349-363. [CrossRef]

48. Landberg, K.; Pederson, E.R.A.; Viaene, T.; Bozorg, B.; Friml, J.; Jonsson, H.; Thelander, M.; Sundberg, E. The moss Physcomitrella patens reproductive organ development is highly organized, affected by the two SHI/STY genes and by the level of active auxin in the SHI/STY expression domain. Plant Physiol. 2013, 162, 1406-1419. [CrossRef]

49. Thelander, M.; Landberg, K.; Sundberg, E. Auxin-mediated developmental control in the moss Physcomitrella patens. J. Exp. Bot. 2018, 69, 277-290. [CrossRef]

50. Woodward, C.; Bemis, S.M.; Hill, E.J.; Sawa, S.; Koshiba, T.; Torii, K.U. Interaction of auxin and ERECTA in elaborating Arabidopsis inflorescence architecture revealed by the activation tagging of a new member of the YUCCA family putative flavin monooxygenases. Plant Physiol. 2005, 139, 192-203. [CrossRef]

51. Marsch-Martinez, N.; Greco, R.; Van Arkel, G.; Herrera-Estrella, L.; Pereira, A. Activation tagging using the En-I maize transposon system in Arabidopsis. Plant Physiol. 2002, 129, 1544-1556. [CrossRef] [PubMed]

52. Rensing, S.A.; Lang, D.; Zimmer, A.D.; Terry, A.; Salamov, A.; Shapiro, H.; Nishiyama, T.; Perroud, P.-F.; Lindquist, E.A.; Kamisugi, Y.; et al. The Physcomitrella genome reveals evolutionary insights into the conquest of land by plants. Science 2008, 319, 64-69. [CrossRef] [PubMed]

53. Ishida, J.K.; Wakatake, T.; Yoshida, S.; Takebayashi, Y.; Kasahara, H.; Wafula, E.; dePamphilis, C.W.; Namba, S.; Shirasu, K. Local auxin biosynthesis mediated by a YUCCA flavin monooxygenase regulates haustorium development in the parasitic plant Phtheirospermum japonicum. Plant Cell 2016, 28, 1795-1814. [CrossRef] [PubMed]

54. Jia, J.; Li, S.; Cao, X.; Li, H.; Shi, W.; Polle, A.; Liu, T.X.; Peng, C.; Luo, Z.B. Physiological and transcriptional regulation in poplar roots and leaves during acclimation to high temperature and drought. Physiol. Plan. 2016, 157, 38-53. [CrossRef] [PubMed]

55. Kim, J.I.; Baek, D.; Park, H.C.; Chun, H.J.; Oh, D.H.; Lee, M.K.; Cha, J.Y.; Kim, W.Y.; Kim, M.C.; Chung, W.S.; et al. Overexpression of Arabidopsis YUCCA6 in potato results in high-auxin developmental phenotypes and enhanced resistance to water deficit. Mol. Plant 2013, 6, 337-349. [CrossRef] [PubMed]

56. Cheol Park, H.; Cha, J.Y.; Yun, D.J. Roles of YUCCAs in auxin biosynthesis and drought stress responses in plants. Plant Signal. Behav. 2013, 8, 337-349. [CrossRef]

57. Lockhart, J. The elegant simplicity of the liverwort Marchantia polymorpha. Plant Cell 2015, 27, 1565. [CrossRef]

58. Zhang, T.; Li, R.; Xing, J.; Yan, L.; Wang, R.; Zhao, Y. The YUCCA-auxin-WOX11 module controls crown root development in rice. Front. Plant Sci. 2018, 9, 523. [CrossRef]

59. Cheng, Y.; Dai, X.; Zhao, Y. Auxin synthesized by the YUCCA flavin monooxygenases is essential for embryogenesis and leaf formation in Arabidopsis. Plant Cell 2007, 19, 2430-2439. [CrossRef]

60. Gallavotti, A.; Barazesh, S.; Malcomber, S.; Hall, D.; Jackson, D.; Schmidt, R.J.; McSteen, P. Sparse inflorescence1 encodes a monocot-specific YUCCA-like gene required for vegetative and reproductive development in maize. Proc. Natl. Acad. Sci. USA 2008, 105, 15196-15201. [CrossRef]

61. Tuskan, G.A.; DiFazio, S.; Jansson, S.; Bohlmann, J.; Grigoriev, I.; Hellsten, U.; Putnam, N.; Ralph, S.; Rombauts, S.; Salamov, A.; et al. The genome of black cottonwood, Populus trichocarpa. Science 2006, 313, 1596-1604. [CrossRef] [PubMed]

62. Abu-Zaitoon, Y.M. Phylogenetic analysis of putative genes involved in the tryptophan-dependent pathway of auxin biosynthesis in rice. Appl. Biochem. Biotechnol. 2014, 172, 2480-2495. [CrossRef] [PubMed]

63. Yue, J.; Hu, X.; Huang, J. Origin of plant auxin biosynthesis. Trends Plant Sci. 2014, 19, 764-770. [CrossRef] [PubMed]

64. Bowman, J.L.; Kohchi, T.; Yamato, K.T.; Jenkins, J.; Shu, S.; Ishizaki, K.; Yamaoka, S.; Nishihama, R.; Nakamura, Y.; Berger, F.; et al. Insights into land plant evolution garnered from the Marchantia polymorpha genome. Cell 2017, 171, 287-304. [CrossRef] [PubMed]

65. Wang, C.; Liu, Y.; Li, S.S.; Han, G.Z. Origin of plant auxin biosynthesis in charophyte algae. Trends Plant Sci. 2014, 19, 741-743. [CrossRef] 
66. Romani, F. Origin of taa genes in charophytes: New insights into the controversy over the origin of auxin biosynthesis. Front Plant Sci. 2017, 8, 1616. [CrossRef]

67. Cashman, J.R. Human and plant flavin-containing monooxygenase N-oxygenation of amines: detoxication vs. bioactivation. Drug Metab. Rev. 2002, 34, 513-521. [CrossRef]

68. Krueger, S.K.; Williams, D.E. Mammalian flavin-containing monooxygenases: Structure/function, genetic polymorphisms and role in drug metabolism. Pharmacol. Ther. 2005, 106, 357-387. [CrossRef]

69. Schlaich, N.L. Flavin-containing monooxygenases in plants: Looking beyond detox. Trends Plant Sci. 2007, 12, 412-418. [CrossRef]

70. Wierenga, R.; Demaeyer, M.; Hol, W. Interaction of pyrophosphate moieties with alpha-helixes in dinucleotide binding-proteins. Biochemistry 1985, 24, 1346-1357. [CrossRef]

71. Cashman, J.R. Structural and catalytic properties of the mammalian flavin-containing monooxygenase. Chem. Res. Toxicol. 1995, 8, 166-181. [CrossRef] [PubMed]

72. Vallon, O. New sequence motifs in flavoproteins: Evidence for common ancestry and tools to predict structure. Proteins 2000, 38, 95-114. [CrossRef]

73. Fraaije, M.W.; Kamerbeek, N.M.; van Berkel, W.J.H.; Janssen, D.B. Identification of a Baeyer-Villiger monooxygenase sequence motif. FEBS Lett. 2002, 518, 43-47. [CrossRef]

74. Cheesman, M.J.; Byron Kneller, M.; Rettie, A.E. Critical role of histidine residues in cyclohexanone monooxygenase expression, cofactor binding and catalysis. Chem.-Biol. Interact 2003, 146, 157-164. [CrossRef]

75. Hou, X.; Liu, S.; Pierri, F.; Dai, X.; Qu, L.-J.; Zhao, Y. Allelic analyses of the Arabidopsis YUC1 locus reveal residues and domains essential for the functions of YUC family of flavin monooxygenases. J. Integr. Plant Biol. 2011, 53, 54-62. [CrossRef]

76. Sairanen, I.; Novak, O.; Pencik, A.; Ikeda, Y.; Jones, B.; Sandberg, G.; Ljung, K. Soluble carbohydrates regulate auxin biosynthesis via PIF proteins in Arabidopsis. Plant Cell 2012, 24, 4907-4916. [CrossRef]

77. Ljung, K.; Hull, A.K.; Celenza, J.; Yamada, M.; Estelle, M.; Normanly, J.; Sandberg, G. Sites and regulation of auxin biosynthesis in Arabidopsis roots. Plant Cell 2005, 17, 1090-1104. [CrossRef]

78. Kriechbaumer, V.; Botchway, S.W.; Hawes, C. Localization and interactions between Arabidopsis auxin biosynthetic enzymes in the TAA/YUC-dependent pathway. J. Exp. Bot. 2017, 68, 4195-4207. [CrossRef]

79. Kriechbaumer, V.; Shaw, R.; Mukherjee, J.; Bowsher, C.G.; Harrison, A.-M.; Abell, B.M. Subcellular distribution of tail-anchored proteins in Arabidopsis. Traffic 2009, 10, 1753-1764. [CrossRef]

80. Kriechbaumer, V.; Wang, P.; Hawes, C.; Abell, B.M. Alternative splicing of the auxin biosynthesis gene YUCCA4 determines its subcellular compartmentation. Plant J. 2012, 70, 292-302. [CrossRef]

81. Ljung, K. Auxin metabolism and homeostasis during plant development. Development 2013, 140, $943-950$. [CrossRef] [PubMed]

82. Majda, M.; Robert, S. The role of auxin in cell wall expansion. Int. J. Mol. Sci. 2018, 19, 951. [CrossRef] [PubMed]

83. Stone, S.L.; Braybrook, S.A.; Paula, S.L.; Kwong, L.W.; Meuser, J.; Pelletier, J.; Hsieh, T.F.; Fischer, R.L.; Goldberg, R.B.; Harada, J.J. Arabidopsis LEAFY COTYLEDON2 induces maturation traits and auxin activity: Implications for somatic embryogenesis. Proc. Natl. Acad. Sci. USA 2008, 105, 3151-3156. [CrossRef] [PubMed]

84. Wójcikowska, B.; Jaskóła, K.; Gąsiorek, P.; Meus, M.; Nowak, K.; Gaj, M.D. LEAFY COTYLEDON2 (LEC2) promotes embryogenic induction in somatic tissues of Arabidopsis, via YUCCA-mediated auxin biosynthesis. Planta 2013, 238, 425-440. [CrossRef]

85. Li, L.C.; Qin, G.J.; Tsuge, T.; Hou, X.H.; Ding, M.Y.; Aoyama, T.; Oka, A.; Chen, Z.; Gu, H.; Zhao, Y.; et al. SPOROCYTELESS modulates YUCCA expression to regulate the development of lateral organs in Arabidopsis. New Phytol. 2008, 179, 751-764. [CrossRef]

86. Rawat, R.; Schwartz, J.; Jones, M.A.; Sairanen, I.; Cheng, Y.; Andersson, C.R.; Zhao, Y.; Ljung, K.; Harmer, S.L. REVEILLE1, a Myb-like transcription factor, integrates the circadian clock and auxin pathways. Proc. Natl. Acad. Sci. USA 2009, 106, 16883-16888. [CrossRef]

87. Sun, J.; Qi, L.; Li, Y.; Chu, J.; Li, C. PIF4-mediated activation of YUCCA8 expression integrates temperature into the auxin pathway in regulating Arabidopsis hypocotyl growth. PLoS Genet. 2012, 8, e1002594. [CrossRef]

88. Goyal, A.; Karayekov, E.; Galvao, V.C.; Ren, H.; Casal, J.J.; Fankhauser, C. Shade promotes phototropism through Phytochrome B-controlled auxin production. Curr. Biol. 2016, 26, 3280-3287. [CrossRef] 
89. Franklin, K.A.; Lee, S.H.; Patel, D.; Kumar, S.V.; Spartz, A.K.; Gu, C.; Ye, S.; Yu, P.; Breen, G.; Cohen, J.D.; et al. PHYTOCHROME-INTERACTING FACTOR 4 (PIF4) regulates auxin biosynthesis at high temperature. Proc. Natl. Acad. Sci. USA 2011, 108, 20231-20235. [CrossRef]

90. Liu, G.; Gao, S.; Tian, H.; Wu, W.; Robert, H.S.; Ding, Z. Local transcriptional control of YUCCA regulates auxin promoted root-growth inhibition in response to aluminium stress in Arabidopsis. PLoS Genet. 2016, 12, e1006360. [CrossRef]

91. Luo, J.; Zhou, J.J. Growth performance, photosynthesis, and root characteristics are associated with nitrogen use efficiency in six poplar species. Environ. Exp. Bot. 2019, 164, 40-51. [CrossRef]

92. Luo, J.; Zhou, J.J.; Masclaux-Daubresse, C.; Wang, N.; Wang, H.; Zheng, B. Morphological and physiological responses to contrasting nitrogen regimes in Populus cathayana is linked to resources allocation and carbon/nitrogen partition. Environ. Exp. Bot. 2019, 162, 247-255. [CrossRef]

93. Kerk, N.M.; Jiang, K.; Feldman, L.J. Auxin metabolism in the root apical meristem. Plant Physiol. 2000, 122, 925-932. [CrossRef] [PubMed]

94. Brumos, J.; Robles, L.M.; Yun, J.; Vu, T.C.; Jackson, S.; Alonso, J.M.; Stepanova, A.N. Local auxin biosynthesis is a key regulator of plant development. Dev. Cell 2018, 47, 306-318.e305. [CrossRef]

95. Blilou, I.; Xu, J.; Wildwater, M.; Willemsen, V.; Paponov, I.; Friml, J.; Heidstra, R.; Aida, M.; Palme, K.; Scheres, B. The PIN auxin efflux facilitator network controls growth and patterning in Arabidopsis roots. Nature 2005, 433, 39-44. [CrossRef]

96. Grieneisen, V.A.; Xu, J.; Maree, A.F.M.; Hogeweg, P.; Scheres, B. Auxin transport is sufficient to generate a maximum and gradient guiding root growth. Nature 2007, 449, 1008-1013. [CrossRef]

97. Won, C.; Shen, X.; Mashiguchi, K.; Zheng, Z.; Dai, X.; Cheng, Y.; Kasahara, H.; Kamiya, Y.; Chory, J.; Zhao, Y. Conversion of tryptophan to indole-3-acetic acid by TRYPTOPHAN AMINOTRANSFERASES OF ARABIDOPSIS and YUCCAs in Arabidopsis. Proc. Natl. Acad. Sci. USA 2011, 108, 18518-18523. [CrossRef]

98. Mashiguchi, K.; Tanaka, K.; Sakai, T.; Sugawara, S.; Kawaide, H.; Natsume, M.; Hanada, A.; Yaeno, T.; Shirasu, K.; Yao, H.; et al. The main auxin biosynthesis pathway in Arabidopsis. Proc. Natl. Acad. Sci. USA 2011, 108, 18512-18517. [CrossRef]

99. Yamamoto, Y.; Kamiya, N.; Morinaka, Y.; Matsuoka, M.; Sazuka, T. Auxin biosynthesis by the YUCCA genes in rice. Plant Physiol. 2007, 143, 1362-1371. [CrossRef]

100. Guo, J.; Wei, J.; Xu, J.; Sun, M.X. Inducible knock-down of GNOM during root formation reveals tissue-specific response to auxin transport and its modulation of local auxin biosynthesis. J. Exp. Bot. 2014, 65, 1165-1179. [CrossRef]

101. Ursache, R.; Miyashima, S.; Chen, Q.; Vatén, A.; Nakajima, K.; Carlsbecker, A.; Zhao, Y.; Helariutta, Y.; Dettmer, J. Tryptophan-dependent auxin biosynthesis is required for HD-ZIP III-mediated xylem patterning. Development 2014, 141, 1250-1259. [CrossRef] [PubMed]

102. de Klerk, G.-J.; van der Krieken, W.; de Jong, J.C. Review the formation of adventitious roots: New concepts, new possibilities. In Vitro Cell. Dev. Biol. Plant 1999, 35, 189-199. [CrossRef]

103. Mu, X.; Luo, J. Evolutionary analyses of INI-like proteins in plants and their roles in nitrate signaling. Cell. Mol. Life Sci. 2019, 76, 3753-3764. [CrossRef] [PubMed]

104. Ahkami, A.H.; Melzer, M.; Ghaffari, M.R.; Pollmann, S.; Ghorbani Javid, M.; Shahinnia, F.; Hajirezaei, M.R.; Druege, U. Distribution of indole-3-acetic acid in Petunia hybrida shoot tip cuttings and relationship between auxin transport, carbohydrate metabolism and adventitious root formation. Planta 2013, 238, 499-517. [CrossRef] [PubMed]

105. Rasmussen, A.; Hosseini, S.A.; Hajirezaei, M.-R.; Druege, U.; Geelen, D. Adventitious rooting declines with the vegetative to reproductive switch and involves a changed auxin homeostasis. J. Exp. Bot. 2015, 66, 1437-1452. [CrossRef] [PubMed]

106. Shang, C.; Yang, H.; Ma, S.; Shen, Q.; Liu, L.; Hou, C.; Cao, X.; Cheng, J. Physiological and transcriptomic changes during the early phases of adventitious root formation in mulberry stem hardwood cuttings. Int. J. Mol. Sci. 2019, 20, 3707. [CrossRef]

107. Druege, U.; Franken, P.; Hajirezaei, M.R. Plant hormone homeostasis, signaling, and function during adventitious root formation in cuttings. Front. Plant Sci. 2016, 7, 381. [CrossRef]

108. Druege, U.; Hilo, A.; Perez-Perez, J.M.; Klopotek, Y.; Acosta, M.; Shahinnia, F.; Zerche, S.; Franken, P.; Hajirezaei, M.R. Molecular and physiological control of adventitious rooting in cuttings: Phytohormone action meets resource allocation. Ann. Bot. 2019, 123, 929-949. [CrossRef] 
109. Sang, Y.L.; Cheng, Z.J.; Zhang, X.S. Endogenous auxin biosynthesis and de novo root organogenesis. J. Exp. Bot. 2016, 67, 4011-4013. [CrossRef]

110. Pan, J.; Zhao, F.; Zhang, G.; Pan, Y.; Sun, L.; Bao, N.; Qin, P.; Chen, L.; Yu, J.; Zhang, Y.; et al. Control of de novo root regeneration efficiency by developmental status of Arabidopsis leaf explants. J. Genet. Genom. 2019, 46, 133-140. [CrossRef]

111. Suzuki, H.; Yokawa, K.; Nakano, S.; Yoshida, Y.; Fabrissin, I.; Okamoto, T.; Baluska, F.; Koshiba, T. Root cap-dependent gravitropic U-turn of maize root requires light-induced auxin biosynthesis via the YUC pathway in the root apex. J. Exp. Bot. 2016, 67, 4581-4591. [CrossRef] [PubMed]

112. Damodaran, S.; Westfall, C.S.; Kisely, B.A.; Jez, J.M.; Subramanian, S. Nodule-enriched Gretchen Hagen 3 enzymes have distinct substrate specificities and are important for proper soybean nodule development. Int. J. Mol. Sci. 2017, 18, 2547. [CrossRef] [PubMed]

113. Kohlen, W.; Ng, J.L.P.; Deinum, E.E.; Mathesius, U. Auxin transport, metabolism, and signalling during nodule initiation: Indeterminate and determinate nodules. J. Exp. Bot. 2018, 69, 229-244. [CrossRef] [PubMed]

114. Kim, J.I.; Sharkhuu, A.; Jin, J.B.; Li, P.; Jeong, J.C.; Baek, D.; Lee, S.Y.; Blakeslee, J.J.; Murphy, A.S.; Bohnert, H.J.; et al. yucca6, a dominant mutation in Arabidopsis, affects auxin accumulation and auxin-related phenotypes. Plant Physiol. 2007, 145, 722-735. [CrossRef] [PubMed]

115. Wang, W.; Xu, B.; Wang, H.; Li, J.; Huang, H.; Xu, L. YUCCA genes are expressed in response to leaf adaxial-abaxial juxtaposition and are required for leaf margin development. Plant Physiol. 2011, 157, 1805-1819. [CrossRef] [PubMed]

116. Scarpella, E.; Barkoulas, M.; Tsiantis, M. Control of leaf and vein development by auxin. Cold Spring Harb. Perspect. Biol. 2010, 2, a001511. [CrossRef]

117. Scanlon, M.J. The polar auxin transport inhibitor N-1-naphthylphthalamic acid disrupts leaf initiation, KNOX protein regulation, and formation of leaf margins in maize. Plant Physiol. 2003, 133, 597-605. [CrossRef]

118. Zgurski, J.M.; Sharma, R.; Bolokoski, D.A.; Schultz, E.A. Asymmetric auxin response precedes asymmetric growth and differentiation of asymmetric leaf1 and asymmetric leaf2 Arabidopsis leaves. Plant Cell 2005, 17, 77-91. [CrossRef]

119. Ostria-Gallardo, E.; Ranjan, A.; Chitwood, D.H.; Kumar, R.; Townsley, B.T.; Ichihashi, Y.; Corcuera, L.J.; Sinha, N.R. Transcriptomic analysis suggests a key role for SQUAMOSA PROMOTER BINDING PROTEIN LIKE, NAC and YUCCA genes in the heteroblastic development of the temperate rainforest tree Gevuina avellana (Proteaceae). New Phytol. 2016, 210, 694-708. [CrossRef]

120. Wang, H.; Cheng, H.; Wang, W.; Liu, J.; Hao, M.; Mei, D.; Zhou, R.; Fu, L.; Hu, Q. Identification of BnaYUCCA6 as a candidate gene for branch angle in Brassica napus by QTL-seq. Sci. Rep. 2016, 6, 38493. [CrossRef]

121. Kim, J.I.; Murphy, A.S.; Baek, D.; Lee, S.W.; Yun, D.J.; Bressan, R.A.; Narasimhan, M.L. YUCCA6 over-expression demonstrates auxin function in delaying leaf senescence in Arabidopsis thaliana. J. Exp. Bot. 2011, 62, 3981-3992. [CrossRef] [PubMed]

122. Hentrich, M.; Sánchez-Parra, B.; Pérez Alonso, M.-M.; Carrasco Loba, V.; Carrillo, L.; Vicente-Carbajosa, J.; Medina, J.; Pollmann, S. YUCCA8 and YUCCA9 overexpression reveals a link between auxin signaling and lignification through the induction of ethylene biosynthesis. Plant Signal. Behav. 2013, 8, e26363. [CrossRef] [PubMed]

123. Pinon, V.; Prasad, K.; Grigg, S.P.; Sanchez-Perez, G.F.; Scheres, B. Local auxin biosynthesis regulation by PLETHORA transcription factors controls phyllotaxis in Arabidopsis. Proc. Natl. Acad. Sci. USA 2013, 110, 1107-1112. [CrossRef] [PubMed]

124. Pagnussat, G.C.; Alandete-Saez, M.; Bowman, J.L.; Sundaresan, V. Auxin-dependent patterning and gamete specification in the Arabidopsis female gametophyte. Science 2009, 324, 1684-1689. [CrossRef]

125. Robert, H.S.; Grones, P.; Stepanova, A.N.; Robles, L.M.; Lokerse, A.S.; Alonso, J.M.; Weijers, D.; Friml, J. Local auxin sources orient the apical-basal axis in Arabidopsis embryos. Curr. Biol. 2013, 23, 2506-2512. [CrossRef]

126. Bai, B.; Su, Y.H.; Yuan, J.; Zhang, X.S. Induction of somatic embryos in Arabidopsis requires local YUCCA expression mediated by the down-regulation of ethylene biosynthesis. Mol. Plant 2013, 6, 1247-1260. [CrossRef]

127. De Jong, M.; Wolters-Arts, M.; Feron, R.; Mariani, C.; Vriezen, W.H. The Solanum lycopersicum auxin response factor 7 (SlARF7) regulates auxin signaling during tomato fruit set and development. Plant J. 2009, 57, 160-170. [CrossRef] 
128. Ruan, Y.-L.; Patrick, J.W.; Bouzayen, M.; Osorio, S.; Fernie, A.R. Molecular regulation of seed and fruit set. Trends Plant Sci. 2012, 17, 656-665. [CrossRef]

129. Abu-Zaitoon, Y.M.; Bennett, K.; Normanly, J.; Nonhebel, H.M. A large increase in IAA during development of rice grains correlates with the expression of tryptophan aminotransferase OsTAR1 and a grain-specific YUCCA. Physiol. Plant. 2012, 146, 487-499. [CrossRef]

130. Schaffer, R.J.; Ireland, H.S.; Ross, J.J.; Ling, T.J.; David, K.M. SEPALLATA1/2-suppressed mature apples have low ethylene, high auxin and reduced transcription of ripening-related genes. AoB Plants 2013, 5, pls047. [CrossRef]

131. Pattison, R.J.; Csukasi, F.; Catalá, C. Mechanisms regulating auxin action during fruit development. Physiol. Plant. 2014, 151, 62-72. [CrossRef] [PubMed]

132. Bielach, A.; Hrtyan, M.; Tognetti, V.B. Plants under stress: Involvement of auxin and cytokinin. Int. J. Mol. Sci. 2017, 18, 1427. [CrossRef] [PubMed]

133. Abrams, M.D. Adaptations and responses to drought in Quercus species of North America. Tree Physiol. 1990, 7, 227-238. [CrossRef] [PubMed]

134. Allen, C.D.; Macalady, A.K.; Chenchouni, H.; Bachelet, D.; McDowell, N.; Vennetier, M.; Kitzberger, T.; Rigling, A.; Breshears, D.D.; Hogg, E.H.; et al. A global overview of drought and heat-induced tree mortality reveals emerging climate change risks for forests. Forest Ecol. Manag. 2010, 259, 660-684. [CrossRef]

135. Cao, X.; Jia, J.; Zhang, C.; Li, H.; Liu, T.; Jiang, X.; Polle, A.; Peng, C.; Luo, Z.B. Anatomical, physiological and transcriptional responses of two contrasting poplar genotypes to drought and re-watering. Physiol. Plant. 2014, 151, 480-494. [CrossRef]

136. Davies, W.J.; Kudoyarova, G.; Hartung, W. Long-distance ABA signaling and its relation to other signaling pathways in the detection of soil drying and the mediation of the plant's response to drought. J. Plant Growth Regul. 2005, 24, 285-295. [CrossRef]

137. Drake, P.L.; Froend, R.H.; Franks, P.J. Smaller, faster stomata: Scaling of stomatal size, rate of response, and stomatal conductance. J. Exp. Bot. 2013, 64, 495-505. [CrossRef]

138. Cha, J.Y.; Kim, W.Y.; Kang, S.B.; Kim, J.I.; Baek, D.; Jung, I.J.; Kim, M.R.; Li, N.; Kim, H.J.; Nakajima, M.; et al. A novel thiol-reductase activity of Arabidopsis YUC6 confers drought tolerance independently of auxin biosynthesis. Nat. Commun. 2015, 6, 8041. [CrossRef]

139. Shi, H.; Chen, L.; Ye, T.; Liu, X.; Ding, K.; Chan, Z. Modulation of auxin content in Arabidopsis confers improved drought stress resistance. Plant Physiol. Biochem. 2014, 82, 209-217. [CrossRef]

140. Lee, M.; Jung, J.H.; Han, D.Y.; Seo, P.J.; Park, W.J.; Park, C.M. Activation of a flavin monooxygenase gene YUCCA7 enhances drought resistance in Arabidopsis. Planta 2012, 235, 923-938. [CrossRef]

141. Lee, H.J.; Jung, J.H.; Llorca, L.C.; Kim, S.G.; Lee, S.; Baldwin, I.T.; Park, C.M. FCA mediates thermal adaptation of stem growth by attenuating auxin action in Arabidopsis. Nat. Commun. 2014, 5, 5473. [CrossRef] [PubMed]

142. Ma, D.; Li, X.; Guo, Y.; Chu, J.; Fang, S.; Yan, C.; Noel, J.P.; Liu, H. Cryptochrome 1 interacts with PIF4 to regulate high temperature-mediated hypocotyl elongation in response to blue light. Proc. Natl. Acad. Sci. USA 2016, 113, 224-229. [CrossRef] [PubMed]

143. Sakata, T.; Oshino, T.; Miura, S.; Tomabechi, M.; Tsunaga, Y.; Higashitani, N.; Miyazawa, Y.; Takahashi, H.; Watanabe, M.; Higashitani, A. Auxins reverse plant male sterility caused by high temperatures. Proc. Natl. Acad. Sci. USA 2010, 107, 8569-8574. [CrossRef] [PubMed]

144. Sakata, T.; Yagihashi, N.; Atsushi, H.J. Tissue-specific auxin signaling in response to temperature fluctuation. Plant Signal. Behav. 2010, 5, 1510-1512. [CrossRef] [PubMed]

145. Kami, C.; Lorrain, S.; Hornitschek, P.; Fankhauser, C. Light-regulated plant growth and development. Curr. Top. Dev. Biol. 2010, 91, 29-66. [PubMed]

146. Casal, J.J. Photoreceptor signaling networks in plant responses to shade. Annu. Rev. Plant Biol. 2013, 64, 403-427. [CrossRef]

147. Michaud, O.; Fiorucci, A.S.; Xenarios, I.; Fankhauser, C. Local auxin production underlies a spatially restricted neighbor-detection response in Arabidopsis. Proc. Natl. Acad. Sci. USA 2017, 114, 7444-7449. [CrossRef]

148. Tao, Y.; Ferrer, J.L.; Ljung, K.; Pojer, F.; Hong, F.; Long, J.A.; Li, L.; Moreno, J.E.; Bowman, M.E.; Ivans, L.J.; et al. Rapid synthesis of auxin via a new tryptophan-dependent pathway is required for shade avoidance in plants. Cell 2008, 133, 164-176. [CrossRef] 
149. Kohnen, M.V.; Schmid-Siegert, E.; Trevisan, M.; Petrolati, L.A.; Sénéchal, F.; Müller-Moulé, P.; Maloof, J.; Xenarios, I.; Fankhauser, C. Neighbor detection induces organ-specific transcriptomes, revealing patterns underlying hypocotyl-specific growth. Plant Cell 2016, 28, 2889-2904. [CrossRef]

150. Nito, K.; Kajiyama, T.; Unten-Kobayashi, J.; Fujii, A.; Mochizuki, N.; Kambara, H.; Nagatani, A. Spatial regulation of the gene expression response to shade in Arabidopsis seedlings. Plant Cell Physiol. 2015, 56, 1306-1319. [CrossRef]

151. Müller-Moulé, P.; Nozue, K.; Pytlak, M.L.; Palmer, C.M.; Covington, M.F.; Wallace, A.D.; Harmer, S.L.; Maloof, J.N. YUCCA auxin biosynthetic genes are required for Arabidopsis shade avoidance. PeerJ 2016, 4, e2574. [CrossRef] [PubMed]

152. Li, L.; Ljung, K.; Breton, G.; Schmitz, R.J.; Pruneda-Paz, J.; Cowing-Zitron, C.; Cole, B.J.; Ivans, L.J.; Pedmale, U.V.; Jung, H.S.; et al. Linking photoreceptor excitation to changes in plant architecture. Genes Dev. 2012, 26, 785-790. [CrossRef] [PubMed]

153. Nozue, K.; Tat, A.V.; Devisetty, U.K.; Robinson, M.; Mumbach, M.R.; Ichihashi, Y.; Lekkala, S.; Maloof, J.N. Shade avoidance components and pathways in adult plants revealed by phenotypic profiling. PloS Genet. 2015, 11, e1004953. [CrossRef] [PubMed]

154. Pacín, M.; Semmoloni, M.; Legris, M.; Finlayson, S.A.; Casal, J.J. Convergence of CONSTITUTIVE PHOTOMORPHOGENESIS 1 and PHYTOCHROME INTERACTING FACTOR signalling during shade avoidance. New Phytol. 2016, 211, 967-979. [CrossRef] [PubMed]

155. Hornitschek, P.; Kohnen, M.V.; Lorrain, S.; Rougemont, J.; Ljung, K.; López-Vidriero, I.; Franco-Zorrilla, J.M.; Solano, R.; Trevisan, M.; Pradervand, S.; et al. Phytochrome interacting factors 4 and 5 control seedling growth in changing light conditions by directly controlling auxin signaling. Plant J. 2012, 71, 699-711. [CrossRef] [PubMed]

156. Pfeiffer, A.; Shi, H.; Tepperman, J.M.; Zhang, Y.; Quail, P.H. Combinatorial complexity in a transcriptionally centered signaling hub in Arabidopsis. Mol. Plant 2014, 7, 1598-1618. [CrossRef]

157. Pacín, M.; Legris, M.; Casal, J.J. COP1 re-accumulates in the nucleus under shade. Plant J. 2013, 75, 631-641. [CrossRef]

158. Iglesias, M.J.; Sellaro, R.; Zurbriggen, M.D.; Casal, J.J. Multiple links between shade avoidance and auxin networks. J. Exp. Bot. 2018, 69, 213-228. [CrossRef]

159. Suzuki, M.; Yamazaki, C.; Mitsui, M.; Kakei, Y.; Mitani, Y.; Nakamura, A.; Ishii, T.; Soeno, K.; Shimada, Y. Transcriptional feedback regulation of YUCCA genes in response to auxin levels in Arabidopsis. Plant Cell Rep. 2015, 34, 1343-1352. [CrossRef]

160. Takato, S.; Kakei, Y.; Mitsui, M.; Ishida, Y.; Suzuki, M.; Yamazaki, C.; Hayashi, K.; Ishii, T.; Nakamura, A.; Soeno, K.; et al. Auxin signaling through SCF ${ }^{\text {TIR1/AFBs }}$ mediates feedback regulation of IAA biosynthesis. Biosci. Biotechnol. Biochem. 2017, 81, 1320-1326. [CrossRef]

161. Yamamuro, C.; Zhu, J.K.; Yang, Z. Epigenetic modifications and plant hormone action. Mol. Plant 2016, 9 , 57-70. [CrossRef] [PubMed]

162. Do, B.H.; Phuong, V.T.B.; Tran, G.B.; Nguyen, N.H. Emerging functions of chromatin modifications in auxin biosynthesis in response to environmental alterations. Plant Growth Regul. 2019, 87, 165-174. [CrossRef]

163. Nishimura, T.; Hayashi, K.; Suzuki, H.; Gyohda, A.; Takaoka, C.; Sakaguchi, Y.; Matsumoto, S.; Kasahara, H.; Sakai, T.; Kato, J.; et al. Yucasin is a potent inhibitor of YUCCA, a key enzyme in auxin biosynthesis. Plant J. 2014, 77, 352-366. [CrossRef] [PubMed]

164. Kakei, Y.; Yamazaki, C.; Suzuki, M.; Nakamura, A.; Sato, A.; Ishida, Y.; Kikuchi, R.; Higashi, S.; Kokudo, Y.; Ishii, T.; et al. Small-molecule auxin inhibitors that target YUCCA are powerful tools for studying auxin function. Plant J. 2015, 84, 827-837. [CrossRef] [PubMed]

(C) 2019 by the authors. Licensee MDPI, Basel, Switzerland. This article is an open access article distributed under the terms and conditions of the Creative Commons Attribution (CC BY) license (http://creativecommons.org/licenses/by/4.0/). 